Syntax Literate: Jurnal Ilmiah Indonesia p-ISSN: 2541-0849 e-ISSN: 2548-1398

Vol. 6, No. 2, Februari 2021

\title{
ANALISIS LAJU PERTUMBUHAN PAJAK HIBURAN DAN KONTRIBUSINYA TERHADAP PENDAPATAN ASLI DAERAH PROVINSI DKI JAKARTA
}

\section{Faisal Reza dan Achmad Lutfi}

Universitas Indonesia, Depok, Jawa Barat, Indonesia

Email: faisaalreza16@gmail.com dan achmad.lutfi@ui.ac.id

\begin{abstract}
The busy city of DKI Jakarta makes it necessary for entertainment for the people in the city, so that the entertainment industry tends to increase. This encourages local governments to further explore the potential for entertainment tax revenue in DKI Jakarta. The realization of entertainment tax revenue in DKI Jakarta from 2015 to 2019 tends to increase every year. The purpose of this study is to determine the growth rate of entertainment tax in DKI Jakarta from 2015 to 2019 and also to find out how much entertainment tax contributes to local revenue in DKI Jakarta. This research uses a quantitative descriptive research approach. The results of this study show that the growth rate of entertainment tax revenue in DKI Jakarta tends to increase every year and the contribution of entertainment tax in DKI Jakarta is still very insufficient, so that entertainment tax cannot be considered a significant component in the contribution of locally-generated revenue in DKI Jakarta Province which is used for the interests of Regional Government Administration.
\end{abstract}

Keywords: Entertainment Tax; Growth Rate; Contribution; Locally-Generated Revenue

\begin{abstract}
Sibuknya kota DKI Jakarta membuat dibutuhkannya suatu hiburan untuk masyarakat di kota tersebut, sehingga industri hiburan cenderung meningkat. Hal tersebut mendorong Pemerintah Daerah untuk semakin menggali potensi penerimaan pajak hiburan di DKI Jakarta. Realisasi penerimaan pajak hiburan di DKI Jakarta dalam kurun waktu tahun 2015 sampai dengan 2019 cenderung meningkat setiap tahunnya. Tujuan dari penelitian ini adalah untuk mengetahui laju pertumbuhan pajak hiburan di DKI Jakarta tahun 2015 sampai dengan tahun 2019 dan juga untuk mengetahui sebesar apa kontribusi pajak hiburan terhadap Pendapatan Asli Daerah di DKI Jakarta. Penelitian ini menggunakan pendekatan penelitian deskriptif kuantitatif. Hasil dari penelitian ini diketahui bahwa laju pertumbuhan penerimaan pajak hiburan di DKI Jakarta cenderung meningkat setiap tahunnya dan kontribusi pajak hiburan di DKI Jakarta masih sangat kurang, sehingga pajak hiburan belum dapat dianggap komponen yang signifikan dalam penyumbang Pendapatan Asli Daerah di Provinsi DKI Jakarta yang digunakan untuk kepentingan penyelenggaraan Pemerintahan Daerah.
\end{abstract}

Kata Kunci: Pajak Hiburan; Laju Pertumbuhan; Kontribusi; Pendapatan Asli Daerah 
Coresponden Author

Email: faisaalreza16@gmail.com

Artikel dengan akses terbuka dibawah lisensi

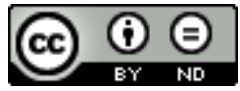

\section{Pendahuluan}

Seiring dengan semakin berkembangnya teknologi informasi telah membuat setiap orang semakin mudah memperoleh informasi dan menikmati hiburan. Hiburan dianggap suatu hal yang dapat menciptakan rasa kebahagiaan kepada seseorang dan dianggap sebagai salah satu cara untuk mengurangi rasa sedih atau stres yang dialami seseorang, namun setiap orang mempunyai sudut pandang masing-masing mengenai hiburan untuk mereka. Definisi hiburan memiliki sifat subjektif karena masing-masing individu mungkin memiliki penafsiran yang berbeda dalam merasakan suatu hiburan. ( Siahaan (2005:197), menyebutkan bahwa hiburan merupakan seluruh jenis permainan ketangkasan, permainan yang ditonton orang, pertunjukkan yang dipungut bayaran, namun tidak termasuk fasilitas berolahraga. Sedangkan (Soekarno, Kitri, \& Utomo, 2016) menjelaskan bahwa hiburan merupakan sesuatu yang bersifat menyenangkan pribadi yang menikmati atau mengkonsumsinya. Dari definisi tersebut, maka secara umum hiburan merupakan semua kegiatan atau perbuatan yang mempunyai tujuan untuk menghibur hati seseorang untuk menjadi senang. Dengan demikian, segala sesuatu yang bersifat menyenangkan dan membuat rileks secara subjektif termasuk sebagai hiburan.

Berbagai bentuk hiburan yang dapat dinikmati diantaranya adalah tontonan, permainan, pertunjukan, atau keramaian yang dinikmati pada umumnya dengan dipungut bayaran dan sebagian terkadang dapat dinikmati secara gratis. Kategori hiburan menurut (Siagian, 2012) adalah pertunjukkan atau keramaian, seperti pertunjukan sandiwara, wayang, pasar malam, kabaret, pameran, olahraga, musik, dan lain-lain yang dipungut bayaran. (Suharsono \& Harahap, 2018) membedakan hiburan menjadi 2, yaitu:

1. Hiburan Permanen, yaitu hiburan yang penyelenggaraannya bersifat tetap karena diselenggarakan pada waktu dan tempat yang tetap, sehingga konsumen dapat mengunjungi lokasi hiburan itu kembali pada waktu dan tempat yang sama. Contoh hiburan permanen diantaranya adalah bioskop, panti pijat, diskotek, dll.;

2. Hiburan Insidental, yaitu hiburan yang yang diselenggarakan dalam jangka waktu terbatas dan tempat yang tidak tetap. Dalam hiburan insindental, konsumen tidak dapat kembali sewaktu-waktu sesuai yang mereka inginkan, namun harus menyesuaikan waktu yang telah ditentukan oleh penyelenggara hiburan. Contoh hiburan insidental diantaranya adalah konser musik.

Industri hiburan belakangan ini memang berkembang pesat terutama di kota-kota besar seperti DKI Jakarta. Kesibukan di DKI Jakarta membuat dibutuhkannya suatu hiburan untuk masyarakat di kota tersebut, sehingga industri hiburan cenderung meningkat. Hal tersebut mendorong Pemerintah Daerah untuk semakin menggali 
potensi penerimaan pajak hiburan di DKI Jakarta. Pajak hiburan merupakan pajak yang dikenakan terhadap penyelenggaraan hiburan. Bayaran yang dipungut atas beberapa jenis hiburan harus dipungut pajak hiburan. (Widiartini, 2012) menyebutkan bahwa hiburan tidak dianggap sebagai konsumsi yang penting, dan bahwa mereka yang dihibur layak untuk membayar mahal untuk hiburan tersebut dan untuk mendukung dana publik. Awalnya pajak hiburan hanya sebatas pada pajak tontonan saja, namun seiiring dengan perjalanan waktu dan berkembangnya zaman membuat pajak hiburan tidak hanya pajak tontonan saja, namun diperluas. Pengertian pajak hiburan menurut (Putri \& Iskandar, 2014) yaitu merupakan suatu pajak yang diselenggarakan di suatu daerah yang dikenakan terhadap semua jasa hiburan dengan memungut bayaran. Berdasarkan definisi tersebut maka dengan kata lain hiburan yang tidak dipungut bayaran tidak dikenakan pajak hiburan oleh Pemerintah Daerah, contohnya seperti pertunjukkan layar tancep dimana semua semua lapisan masyarakat dapat menikmati hiburan tersebut tanpa dipungut bayaran, walaupun saat ini hiburan yang tidak dipungut bayaran seperti itu sudah jarang ditemui terutama di kota-kota besar.

Menurut (Block et al., 2009) menyebutkan bahwa pajak hiburan sesuai apabila dimasukkan kedalam kategori Pajak Daerah karena lokasi hiburan mudah diketahui, sehingga penentuan Pemerintah Daerah sebagai pemungut pajak tidak sulit dilakukan. Selain itu, kewajiban pajak hiburan yang dilakukan oleh pengusaha hiburan membuat biaya pemungutan pajak hiburan menjadi lebih efisien.

Undang-undang otonomi daerah yang diberlakukan membuat sejumlah daerah memiliki kewenangan dan tanggung jawab sendiri untuk membiayai pengeluaran daerah tersebut dan mencari sumber penghasilan dari Pendapatan Asli Daerah tersebut. Diterbitkannya Undang-Undang No. 28 Tahun 2009 tentang Pajak Daerah dan Retribusi Daerah membuat Peraturan Daerah mengenai pajak daerah mengacu pada UndangUndang tersebut. Kemudian pada tahun 2010 diterbitkanlah Peraturan Daerah No. 6 Tahun 2010 tentang Ketentuan Umum Pajak Daerah dan Peraturan Daerah No. 13 Tahun 2010 tentang Pajak Hiburan yang mengatur mengenai pemungutan pajak hiburan di DKI Jakarta, kemudian pada tahun 2015 diterbitkan Peraturan Daerah No. 3 Tahun 2015 tentang Pajak Hiburan sebagai pengganti Peraturan Daerah No. 13 Tahun 2010.

Pada Peraturan Daerah No. 3 Tahun 2015 terdapat beberapa perubahan tarif pajak sebagai upaya Pemerintah Daerah untuk dapat meningkatkan penerimaan pajak hiburan di DKI Jakarta. Realisasi penerimaan pajak hiburan di DKI Jakarta sejak diterbitkannya Peraturan Daerah No. 3 Tahun 2015 cenderung meningkat dari tahun 2015 sampai dengan 2019, seperti terlihat pada tabel 1.

\section{Tabel 1}

\section{Penerimaan Pajak Hiburan di DKI Jakarta}

\begin{tabular}{cc}
\hline Tahun & Realisasi \\
\hline 2015 & Rp. 608.548.867.617 \\
\hline 2016 & Rp. 769.540.465.131 \\
\hline 2017 & Rp. 755.043.772.182 \\
\hline 2018 & Rp. 833.995.184.987 \\
\hline
\end{tabular}




Sumber: Badan Pendapatan Daerah Provinsi DKI Jakarta

Meningkatnya realisasi pajak hiburan tersebut tidak serta merta menunjukkan bahwa pemungutan pajak hiburan sudah efektif dan efisien, ada banyak faktor yang menentukan apakah pemungutan pajak hiburan sudah efektif. Selain itu, karena sistem pemungutan pajak hiburan bersifat self assessment maka fiskus juga harus melakukan pengawasan lebih mendalam terhadap kepatuhan Wajib Pajak, karena menurut penelitian (Diamastuti (2016)) menyebutkan bahwa sistem self assessment dapat mengakibatkan terjadinya penghindaran pajak, penggelapan pajak dan tunggakan pajak. Hal-hal tersebut tentu saja dapat menghambat realisasi penerimaan pajak hiburan yang mengakibatkan pertumbuhan pajak hiburan terganggun.

Naiknya tarif pajak beberapa jenis hiburan sejak diterbitkannya Peraturan Daerah No. 3 Tahun 2015 diharapkan dapat membuat laju pertumbuhan pajak hiburan juga meningkat. (Astuti \& Yudea, 2016) menyebutkan bahwa diketahuinya pertumbuhan untuk masing-masing komponen sumber pendapatan dan pengeluaran dapat digunakan untuk mengevaluasi potensi-potensi yang perlu mendapat perhatian. Penelitian mengenai analisis laju pertumbuhan pajak daerah dilakukan oleh (Astuti \& Yudea, 2016) yang meneliti mengenai Analisis Laju Pertumbuhan Pajak Bumi Dan Bangunan Perdesaan Dan Perkotaan Dan Kontribusinya Terhadap Pendapatan Asli Daerah Kota Balikpapan. Hasil penelitiannya menyebutkan jika laju pertumbuhan Pajak Bumi dan Bangunan Perdesaan dan Perkotaan (PBB-P2) sangat meningkat di Pamekasan setiap tahunnya. Namun, pada penelitian ini yang akan diukur laju pertumbuhannya adalah pajak hiburan di DKI Jakarta.

Kenaikan tarif pajak hiburan juga diharapkan dapat semakin meningkatkan kontribusi penerimaan pajak terhadap Pendapatan Asli Daerah di DKI Jakarta, menurut (Cindoswari, 2016) menyebutkan bahwa kontribusi merupakan bentuk iuran dana atau uang, bantuan pemikiran, tenaga, materi, dan segala bentuk bantuan lainnya yang dapat membantu mensukseskan kegiatan pada suatu forum, perkumpulan dan lain-lain. Sedangkan tujuan adanya Pendapatan Asli Daerah adalah untuk memberi kewenangan setiap daerah masing-masing dapat membiayai pelaksanaan otonomi daerah sebagai bentuk desentralisasi. Menurut (Nurcholis, 2013) Pendapatan Asli Daerah (PAD) adalah pendapatan yang didapatkan setiap daerah dari penerimaan pajak daerah, retribusi daerah, laba perusahaan daerah dan yang sah. Sedangkan menurut Undang-Undang No. 28 Tahun 2009 tentang Pajak Daerah dan Retribusi Daerah, pengertian Pendapatan Asli Daerah (PAD) yaitu merupakan sumber keuangan daerah yang digali dari wilayah daerah yang bersangkutan yang terdiri dari hasil pajak daerah, hasil retribusi daerah, hasil pengelolaan kekayaan daerah yang dipisahkan dan lain-lain Pendapatan Asli Daerah yang sah. Sehingga secara umum pengertian Pendapatan Asli Daerah adalah pendapatan yang diperoleh dari usaha dan kinerja Pemerintah Daerah dalam menggali dan memanfaatkan sumber keuangan daerahnya dalam membiayai penyelenggaraan Pemerintahan Daerah tersebut. 
Diskresi suatu daerah dalam menggunakan Pendapatan Asli Daerah akan semakin tinggi apabila kemampuan daerah tersebut dalam menghasilkan Pendapatan Asli Daerah juga meningkat sehingga aspirasi, kebutuhan, dan prioritas pembangunan dapat segera dilaksanakan. Selain itu, tingkat kemandirian keuangan suatu daerah akan semakin baik dan kemampuan daerah dalam membiayai kegiatan pembangunan daerah oleh Pemerintah Daerah juga akan semakin meningkat apabila proporsi Pendapatan Asli Daerah terhadap penerimaan daerah dalam Anggaran Pendapatan dan Belanja Daerah juga meningkat. Pajak Daerah merupakan penyumbang terbesar Pendapatan Asli Daerah, sejalan dengan penelitian yang dilakukan oleh (Sipakoly, 2018) yang menjelaskan bahwa pajak daerah memiliki pengaruh yang positif dan signifikan terhadap Pendapatan Asli Daerah.

Kontribusi pajak hiburan terhadap Pendapatan Asli Daerah merupakan seberapa besar sumbangsih atau peran pajak hiburan terhadap Pendapatan Asli Daerah secara keseluruhan. Semakin besar potensi penerimaan pajak hiburan, maka seharusnya semakin besar juga target dan realisasi penerimaan pajak hiburan tersebut dimana hal tersebut dapat mendorong berkurangnya ketergantungan Pemerintah Daerah kepada Pemerintah Pusat.

Penelitian sebelumnya mengenai kontribusi pajak hiburan dilakukan oleh (Rahmawati \& Fajar, 2017) dengan penelitian mengenai Kontribusi Pajak Hiburan Dalam Meningkatkan Pendapatan Asli Daerah (PAD) Pada Dinas Pendapatan Kabupaten Pamekasan. Penelitian tersebut bertujuan untuk mengetahui besarnya kontribusi pajak hiburan terhadap Pendapatan Asli Daerah dan berapa besar efektifitas pajak hiburan di Kabupaten Pamekasan. Tingkat efektifitas tersebut menunjukkan bahwa pemungutan pajak hiburan oleh Pemerintah Kabupaten Pamekasan berjalan sangat efektif.

Untuk mengetahui kontribusi suatu pajak daerah dapat dilakukan dengan membandingkan penerimaan pajak daerah pada periode tertentu dengan penerimaan Pendapatan Asli Daerah pada periode tertentu pula. Semakin besar hasilnya berarti semakin besar pula peranan pajak daerah terhadap Pendapatan Asli Daerah, begitu pula sebaliknya jika hasil perbandingannya terlalu kecil berarti peranan pajak daerah terhadap Pendapatan Asli Daerah juga kecil.

Berdasarkan hal-hal tersebut, maka tujuan dari penelitian ini adalah untuk mengetahui laju pertumbuhan pajak hiburan di DKI Jakarta dan juga untuk mengetahui sebesar apa kontribusi pajak hiburan terhadap Pendapatan Asli Daerah di DKI Jakarta paa periode tahun 2015 sampai dengan tahun 2019.

\section{Metode Penelitian}

Penelitian ini menggunakan pendekatan penelitian deskriptif kuantitatif, yaitu dimana data yang diperoleh dalam proses penelitian ini diolah dan selanjutnya dianalisis untuk mendapatkan hasil penelitian. (Watuseke \& Pangemanan, 2016) menyebutkan bahwa data kuantitatif merupakan suatu data yang dapat dinyatakan dalam bentuk angka-angka. Sedangkan penelitian deskriptif menurut (Sekaran \& Shawis, 2009) 
dilakukan untuk memastikan kemampuan mendeskripsikan karakteristik variabel yang diteliti dalam suatu situasi. Sehingga penelitian deskriptif kuantitatif adalah suatu metode untuk menganalisis data yang menggunakan angka-angka dalam menarik kesimpulan dari kejadian-kejadian yang dapat diukur. Dalam penelitian ini adalah dengan melakukan perbandingan terhadap hasil perhitungan penelitian. Jenis data yang digunakan dalam penelitian ini adalah data kuantitatif karena peneliti menggunakan data-data yang berhubungan dengan angka-angka.

Penelitian ini menggunakan teknik pengumpulan data dengan metode dokumentasi dan wawancara. Metode dokumentasi adalah suatu metode pengumpulan data dengan mengumpulkan data-data atau informasi dari buku atau laporan-laporan yang berhubungan dengan penelitian ini agar didapatkan hasil penelitian akuntabel. Selain itu, juga melakukan metode wawancara dengan mengajukan pertanyaan kepada pihak informan yang terkait dengan penelitian yang dilakukan.

Teknik analisis data yang digunakan dalam penelitian ini yaitu analisis deskriptif kuantitatif, yaitu dengan menyajikan dan mendeskripsikan data-data yang diperoleh dengan menggambarkan secara apa adanya sesuai dengan realita yang ada. Pada penelitian ini langkahnya sebagai berikut:

1. Laju Pertumbuhan Pajak Hiburan

Menghitung laju pertumbuhan penerimaan dari pajak hiburan menggunakan rumus sebagai berikut:

$$
\text { GX }=\frac{\mathbf{X t}-\mathbf{X}(\mathrm{t}-1)}{\mathrm{X}(\mathrm{t}-1)} \times 100 \%
$$

Sumber: Abdul Halim dalam Astuti dan Widea (2016)

Keterangan:

$\mathrm{Xt}-\mathrm{X}(\mathrm{t}-1)$

$\mathrm{GX}=\mathrm{x} 100 \%$

$\mathrm{X}(\mathrm{t}-1)$

$\mathrm{Gx}=$ Laju pertumbuhan pajak hiburan/tahun

$\mathrm{Xt}=$ Tahun realisasi penerimaan pajak hiburan

$\mathrm{t} \mathrm{X}(\mathrm{t}-1)=$ Realisasi penerimaan pajak hiburan pada tahun sebelumnya

2. Kontribusi Pajak Hiburan terhadap Pendapatan Asli Daerah (PAD)

Menghitung kontribusi penerimaan pajak hiburan terhadap Pendapatan Asli

Daerah (PAD), maka rumus yang digunakan yaitu:

\section{Kontribusi Pajak Hiburan $=\frac{\text { Realisasi Penerimaan Pajak Hiburan }}{100 \%}$ \\ Realisasi Penerimaan PAD}

Sumber: Abdul Halim dalam Astuti dan Widea (2016)

(Halim, 2017) juga menyebutkan klasifikasi kriteria kontribusi pajak hiburan sebagai berikut: 
Tabel 2

Klasifikasi Kriteria Nilai Kontribusi Pajak Hiburan

\begin{tabular}{cc}
\hline Prosentase & Kriteria \\
\hline$\geq 50$ & Sangat baik \\
\hline $40-50$ & Baik \\
\hline $30-40$ & Sedang \\
\hline $20-30$ & Cukup \\
\hline $10-20$ & Kurang \\
\hline$\leq 10$ & Sangat kurang \\
\hline
\end{tabular}

Sumber: Halim dalam Fajar (2017)

Permasalahan pada penelitian ini hanya akan difokuskan pada Analisis Laju Pertumbuhan Pajak Hiburan dan Kontribusinya Terhadap Pendapatan Asli Daerah Provinsi DKI Jakarta.

\section{Hasil dan Pembahasan}

\section{Laju Pertumbuhan Pajak Hiburan DKI Jakarta}

Pemerintah Daerah tentunya mengharapkan pertumbuhan pajak hiburan dapat terus meningkat setiap tahunnya. Karena hal tersebut juga dapat meningkatkan Pendapatan Asli Daerah yang digunakan untuk membiayai kegiatan Pemerintah Daerah untuk kepentingan bersama. Namun jika pertumbuhan pajak hiburan tidak meningkat atau mengalami penurunan dapat membuat citra yang negatif terhadap kinerja Pemerintah Daerah dalam menggali potensi penerimaan pajak hiburan, namun hal tersebut tidak serta merta dapat menyalahkan Pemerintah Daerah karena terdapat faktor-faktor lain yang dapat mempengaruhi pertumbuhan pajak hiburan, seperti misalkan ondisi ekonomi yang sedang lesu atau bahkan wabah atau pandemi penyakit yang dapat mempengaruhi penerimaan pajak daerah.

Laju pertumbuhan pajak hiburan di DKI Jakarta dari tahun 2015 sampai dengan 2019 dapat dilihat pada tabel 2, dengan menggunakan data target penerimaan dan realisasi pajak hiburan yang didapat peneliti (sumber: Badan Pendapatan Daerah Provinsi DKI Jakarta) dan rumus Halim dalam (Astuti \& Yudea, 2016), maka laju pertumbuhan pajak hiburan di DKI Jakarta sebagai berikut: 
Tabel 3

Laju Pertumbuhan Pajak Hiburan DKI Jakarta

\begin{tabular}{ccccc}
\hline Tahun & Target & Realisasi & Xt - X (t-1) (\%) & GX (\%) \\
\hline 2015 & $\mathrm{Rp550.000.000.000}$ & $\mathrm{Rp} .608 .548 .867 .617$ & $\mathrm{Rp} 107.174 .409 .314$ & $18 \%$ \\
\hline 2016 & $\mathrm{Rp} 750.000 .000 .000$ & $\mathrm{Rp} .769 .540 .465 .131$ & $\mathrm{Rp} 160.991 .597 .514$ & $21 \%$ \\
\hline 2017 & $\mathrm{Rp} 800.000 .000 .000$ & $\mathrm{Rp} .755 .043 .772 .182$ & $-\mathrm{Rp} 14.496 .692 .949$ & $-2 \%$ \\
\hline 2018 & $\mathrm{Rp} 900.000 .000 .000$ & $\mathrm{Rp} .833 .995 .184 .987$ & $\mathrm{Rp} 78.951 .412 .805$ & $9 \%$ \\
\hline 2019 & $\mathrm{Rp} 850.000 .000 .000$ & $\mathrm{Rp} .859 .007 .050 .478$ & $\mathrm{Rp} 25.011 .865 .491$ & $3 \%$ \\
\hline
\end{tabular}

Sumber: Diolah Peneliti

Dari tabel 3 tersebut terlihat jika laju pertumbuhan Pajak Hiburan dari tahun 2015 sampai dengan 2019 mengalami pertumbuhan yang cukup stabil sejak diberlakukannya Peraturan Daerah Provinsi DKI Jakarta No. 3 Tahun 2015 tentang Pajak Hiburan. Pada tahun 2015 laju pertumbuhan pajak hiburan mengalami pertumbuhan sebesar $18 \%$ dibandingkan tahun 2014 dan selanjutnya penerimaan pajak hiburan pada tahun 2016 juga tetap stabil dengan mengalami pertumbuhan sebesar $21 \%$ dibandingkan penerimaan pajak hiburan tahun 2015. Namun, pada tahun 2017 terjadi penurunan realisasi penerimaan pajak dibandingkan penerimaan pajak hiburan tahun 2016 dengan persentase sebesar -2\%. Pada tahun 2018 dan 2019 laju pertumbuhan penerimaan pajak hiburan juga meningkat sebesar 9\% dan $3 \%$, walaupun laju pertumbuhan tersebut tidak sebesar laju pertumbuhan pada tahun 2015 dan 2015, namun jika dilihat secara umum, maka laju pertumbuhan pajak hiburan di DKI Jakarta dari tahun 2015 sampai dengan tahun 2015 cenderung cukup stabil walaupun sempat mengalami penurunan pada tahun 2017. Menurut hasil wawancara dengan Devri Prawitra selaku staf Bidang Perencanaan dan Pengembangan Badan Pendapatan Daerah Provinsi DKI Jakarta, menjelaskan alasan mengapa penerimaan pajak hiburan di DKI Jakarta menurun pada tahun 2017, yaitu:

"jadi untuk pajak daerah di tahun 2017 itu fokusnya lebih banyak terkait dengan bumi dan bangunan antara lain PBB dan BPHTB, dimana penerimaan BPHTB termasuk yang paling tinggi untuk tahun 2017, sehingga akhirnya fokus utamanya lebih banyak tertuju pada PBB dan BPHTB, walaupun kami juga melakukan usaha di jenis pajak-pajak lainnya, sehingga akhirnya 2 (dua) jenis pajak tersebut yang menjadi primadona penerimaan DKI Jakarta tahun 2017. Selain itu, untuk tahun 2017 terkait dengan penagihan, kami belum terlalu masif untuk melakukan penagihan pajak dengan surat paksa. karena masih belum maksimalnya peran dari juru sita dalam melakukan penagihan pajak dengan surat paksa. Selain itu, belum adanya sistem pembayaran elektronik yang baik membuat pertambahan penerimaan pajak dari tempat hiburan tidak terdata dengan baik." 
Menurut Devri Prawitra selaku narasumber menjelaskan bahwa terjadinya penurunan penerimaan pajak hiburan di DKI Jakarta tahun 2017 diantaranya adalah karena di tahun 2017 tersebut Badan Pendapatan Daerah sebagai satuan kerja yang mengurusi terkait pajak daerah lebih fokus terhadap penerimaan PBB-P2 dan BPHTB namun tetap berusaha untuk mengoptimalkan penerimaan jenis pajak daerah lainnya, selain itu peran juru sita pajak pada tahun tersebut belum optimal, dan juga belum adanya sistem pembayaran elektronik juga mempengaruhi penerimaan pajak hiburan tahun 2017.

\section{Kontribusi Pajak Hiburan terhadap Pendapatan Asli Daerah (PAD) Provinsi DKI Jakarta}

Mengukur atau menghitung sumbangsih atau kontribusi pajak hiburan di DKI Jakarta dapat dilakukan dengan melakukan analisis kontribusi pajak hiburan terhadap Pendapatan Asli Daerah (PAD), yaitu dengan melakukan perbandingan hasil analisis kontribusi tersebut dari tahun 2015 sampai dengan 2019 dimana dari hasil analisis tersebut akan terlihat kontribusi pajak hiburan dari yang terbesar sampai yang terkecil dari tahun ke tahun dalam jangka waktu 2015 sampai dengan 2019. Sehingga seberapa besar peran pajak hiburan terhadap Pendapatan Asli Daerah di Provinsi DKI Jakarta dapat diketahui dengan menggunakan kriteriakriteria yang sudah ditentukan. Pada tabel 4 terlihat realisasi penerimaan pajak hiburan dan Pendapatan Asli Daerah Provinsi DKI Jakarta (sumber: Badan Pendapatan Daerah), yang kemudian diolah untuk mendapatkan hasil analisis kontribusinya.

Tabel 4

Kontribusi Penerimaan Pajak Hiburan Terhadap Pendapatan Asli Daerah (PAD) Provinsi DKI Jakarta

\begin{tabular}{ccccc}
\hline Tahun & $\begin{array}{c}\text { Realisasi Pajak } \\
\text { Hiburan }\end{array}$ & $\begin{array}{c}\text { Pendapatan Asli } \\
\text { Daerah }\end{array}$ & Kontribusi & Kriteria \\
\hline 2015 & Rp.608.548.867.617 & Rp.33.686.176.815.708 & $1,81 \%$ & Sangat Kurang \\
\hline 2016 & Rp.769.540.465.131 & Rp.36.888.017.587.716 & $2,09 \%$ & Sangat Kurang \\
\hline 2017 & Rp.755.043.772.182 & Rp.43.901.488.807.743 & $1,72 \%$ & Sangat Kurang \\
\hline 2018 & Rp.833.995.184.987 & Rp.43.327.136.602.811 & $1,92 \%$ & Sangat Kurang \\
\hline 2019 & Rp.859.007.050.478 & Rp.45.707.400.003.802 & $1,88 \%$ & Sangat Kurang \\
\hline \multirow{5}{*}{ Rata-Rata } & & $\mathbf{1 , 8 8 \%}$ & Sangat \\
& & & & Kurang \\
\hline
\end{tabular}

Sumber: Diolah Peneliti

Pada analisis yang terlihat di tabel 4, dapat dilihat bahwa kontribusi pajak hiburan terhadap Pendapatan Asli Daerah Provinsi DKI Jakarta pada tahun 2015 
masuk kriteria sangat kurang dengan kontribusi sebesar 1,81\%, kemudian pada tahun 2016 persentase kontribusinya meningkat menjadi 2,09\% dibandingkan dengan tahun 2015, namun kriterianya tetap sangat kurang. Tahun 2017 persentase kontribusinya sedikit menurun jika dibandingkan tahun 2016 dengan kontribusi sebesar 1,72\% dengan kriteria sangat kurang, selanjutnya pada tahun 2018 persentase kontribusi sedikit meningkat dibandingkan tahun 2017 menjadi 1,92\% dengan kriteria sangat kurang. Pada tahun 2019, persentase kontribusi apabila dibandingkan dengan tahun 2018 agak sedikit mengalami penurunan menjadi $1,88 \%$ dan tetap masuk pada kriteria sangat kurang. Sehingga dalam kurun waktu tahun 2015 sampai dengan tahun 2019 rata-rata kontribusi realisasi penerimaan pajak hiburan terhadap realisasi Pendapatan Asli Daerah Provinis DKI Jakarta adalah sebesar 1,88\% dan termasuk kedalam kriteria sangat kurang.

Dari analisis tersebut, dapat terlihat bahwa kontribusi realisasi pajak hiburan terhadap realisasi Pendapatan Asli Daerah (PAD) Provinsi DKI Jakarta sedikit fluktuatif dimana persentase kontribusinya mengalami naik turun dalam jangka waktu tahun 2015 sampai dengan tahun 2019. Selain itu, kontribusi realisasi pajak hiburan terhadap realisasi Pendapatan Asli Daerah (PAD) Provinsi DKI Jakarta dalam jangka waktu tersebut selalu masuk dalam kriteria sangat kurang, sehingga terlihat bahwa pajak hiburan belum dapat memberikan kontribusi yang signifikan terhadap Pendapatan Asli Daerah (PAD) Provinsi DKI Jakarta. Wawancara dengan Devri Prawitra selaku staf Bidang Perencanaan dan Pengembangan Badan Pendapatan Daerah Provinsi DKI Jakarta menjelaskan beberapa alasan mengapa penerimaan pajak hiburan di DKI Jakarta belum terlalu signifikan terhadap Pendapatan Asli Daerah, yaitu:

"ketika kita berbicara potensi maka berhubungan dengan jumlah dari objek itu sendiri, jumlah objek pajak hiburan yang ada di Jakarta itu ya kalau dibandingkan dengan pajak restoran dan pajak hotel itu tidak lebih banyak dari dua jenis pajak tersebut dan itu juga yang membuat potensi mereka nggak terlalu banyak dibandingkan jumlah pajak yang saya sebutkan sebelumnya, sehingga potensi pajak hiburan terhadap Pendapatan Asli Daerah DKI Jakarta tidak terlalu signifikan. Selain itu, walaupun tarif pajak mengalami kenaikan, namun yang berubah itu untuk untuk beberapa jenis hiburan saja, sehingga belum secara signifikan meningkatkan penerimaan pajak hiburan."

Menurut Devri Prawitra selaku narasumber menjelaskan beberapa penyebab mengapa penerimaan pajak hiburan di DKI Jakarta belum terlalu signifikan terhadap Pendapatan Asli Daerah, yaitu diantaranya dikarenakan jumlah objek pajak hiburan yang tidak sebanyak restoran ataupun hotel dan juga kenaikan tarif pajak hiburan untuk beberapa jenis hiburan tidak mempengaruhi secara signifikan penerimaan pajak hiburan di DKI Jakarta karena kenaikan pajak hiburan tersebut hanya untuk beberapa jenis hiburan dikarenakan tarif pajak hiburan di DKI Jakarta bervariasi tidak hanya satu tarif saja. 


\section{Kesimpulan}

Sesuai dengan hasil dan pembahasan diatas, maka dapat disimpulkan hal-hal berikut: pertama, laju pertumbuhan pajak hiburan Provinsi DKI Jakarta dalam kurun waktu tahun 2015 sampai dengan 2019 cenderung mengalami kenaikan, namun terjadi anomali pada tahun 2017 dimana laju pertumbuhan menurun karena terjadi penurunan realisasi penerimaan pajak yaitu sebesar $-2 \%$ apabila dibandingkan dengan penerimaan pajak hiburan tahun 2016. Sehingga dari hasil penelitian tersebut dapat disimpulkan bahwa laju pertumbuhan penerimaan pajak hiburan di DKI Jakarta cenderung meningkat setiap tahunnya.

Kedua kontribusi penerimaan pajak hiburan terhadap realisasi Pendapatan Asli Daerah masih sangat kurang, dimana kontribusi pajak hiburan terhadap Pendapatan Asli Daerah dalam jangka waktu tahun 2015 sampai dengan tahun 2019 rata-rata adalah sebesar 1,88\%. Selain itu, kontribusi pajak hiburan terhadap Pendapatan Asli Daerah di Provinsi DKI Jakarta masih fluktuatif atau masih naik turun. Hal tersebut menunjukkan bahwa kontribusi pajak hiburan di DKI Jakarta masih sangat kurang, sehingga pajak hiburan belum dapat dianggap komponen yang signifikan dalam penyumbang Pendapatan Asli Daerah di Provinsi DKI Jakarta yang digunakan untuk kepentingan Penyelenggaraan Pemerintahan Daerah. 


\section{BIBLIOGRAFI}

Astuti, Wigi, \& Yudea, Yudea. (2016). Analisis Laju Pertumbuhan Pajak Bumi Dan Bangunan Perdesaan Dan Perkotaan Dan Kontribusinya Terhadap Pendapatan Asli Daerah Kota Balikpapan. Forum Ekonomi, 18(1).

Block, Keith I., Block, Penny B., Reynolds Fox, Susan, Stouffer Birris, Jamie, Feng, April Y., De La Torre, Michael, Nathan, Deva, Tothy, Peter, Maki, Amanda K., \& Gyllenhaal, Charlotte. (2009). Making Circadian Cancer Therapy Practical. Integrative Cancer Therapies, 8(4), 371-386.

Cindoswari, Ageng Rara. (2016). Perilaku Komunikasi Etnis Sunda Pendatang Dalam Adaptasi Ekonomi, Sosial Dan Budaya Pada Majelis Ta'lim Paguyuban Babul Akhirat Di Kota Batam. Jurnal Komunikasi Islam, 6(2), 44-66.

Halim, Totok Eko Nur. (2017). Strategi Komunikasi Dakwah Kyai Aminoto Di Kecamatan Ngebel Kabupaten Ponorogo. Iain Ponorogo.

Nurcholis, Moch. (2013). Reorientasi Jihâd Fî Sabîlillah; Menimbang Kebodohan Dan Kemiskinan Sebagai Musuh Bersama. Tafáqquh: Jurnal Penelitian Dan Kajian Keislaman, 1(2), 22-38.

Putri, Noventi Ersa, \& Iskandar, Dadang. (2014). Analisis Preferensi Konsumen Dalam Penggunaan Social Messenger Di Kota Bandung Tahun 2014 (Studi Kasus: Line, Kakaotalk, Wechat, Whatsapp). Jurnal Manajemen Indonesia, 14(2), 110-126.

Rahmawati, Masayu, \& Fajar, Catur Martian. (2017). Pengaruh Pendapatan Asli Daerah Dan Dana Perimbangan Terhadap Belanja Daerah Kota Bandung. Jurnal Kajian Akuntansi, 1(1).

Sekaran, Prabhu, \& Shawis, Rang. (2009). Perineal Groove: A Rare Congenital Abnormality Of Failure Of Fusion Of The Perineal Raphe And Discussion Of Its Embryological Origin. Clinical Anatomy: The Official Journal Of The American Association Of Clinical Anatomists And The British Association Of Clinical Anatomists, 22(7), 823-825.

Siagian, Sahat. (2012). Pengaruh Strategi Pembelajaran Dan Gaya Belajar Terhadap Hasil Belajar Ipa. Jurnal Teknologi Pendidikan, 5(01), 193-208.

Sipakoly, Selly. (2018). Analisis Pengaruh Serta Pertumbuhan Pajak Daerah Dan Retribusi Daerah Terhadap Pendapatan Asli Daerah Kota Ambon. Jurnal Maneksi, $5(1), 32-43$.

Soekarno, Subiakto, Kitri, Mandra Lazuardi, \& Utomo, Suryo. (2016). Capital Structure Determinants And The Speed Of Adjustment Towards Capital Structure Target: Evidence From Indonesian State-Owned Enterprises. International Journal of Monetary Economics And Finance, 9(4), 388-400. 
Faisal Reza dan Achmad Lutfi

Suharsono, Agus, \& Harahap, Burhanudin. (2018). The Development Of Tax Law Application Formula In Indonesia From Irac Into Ireac. Shs Web Of Conferences, 54, 6006. Edp Sciences.

Watuseke, Chlief, \& Pangemanan, Sifrid S. (2016). Analisis Potensi Pajak Hiburan Di Kota Manado. Jurnal Emba: Jurnal Riset Ekonomi, Manajemen, Bisnis Dan Akuntansi, 4(1).

Widiartini, Ni Ketut. (2012). Umpan Balik Model Pembelajaran Pada Materi Membuat Pola Busana. Jurnal Evaluasi Pendidikan, 3(2), 188-200. 